\title{
RARE CASE OF GIANT CELL TUMOUR ON DORSAL ASPECT OF TENDON SHEATH IN DISTAL INTERPHALANGEAL JOINT OF MIDDLE FINGER LEFT HAND: CASE REPORT
}

\author{
Maruthi C.V1, Roshan Pais², Vedashree M.K³
}

HOW TO CITE THIS ARTICLE:

Maruthi CV, Roshan Pais, Vedashree MK. "Rare case of giant cell tumour on dorsal aspect of tendon sheath in distal interphalangeal joint of middle finger left hand: case report". Journal of Evolution of Medical and Dental Sciences 2013; Vol2, Issue 37, September 16; Page: 7024-7027.

ABSTRACT: INTRODUCTION: Giant cell tumours of the tendon sheath are the second commonest tumours of the hand after ganglion cysts. Usually they involve volar aspect of the proximal interphalangeal joint of fingers. Here is a case where dorsal aspect of the distal interphalangeal joint of the middle finger is involved which is a rare presentation. CASE DETAILS: $47 \mathrm{yrs}$ male patient came with swelling in the middle finger of left hand since two years, examination of it reveals $2.5 \times 2$ $\mathrm{cm}$ firm lobulated swelling adherent to underlying tissues, skin over it is free from the swelling. Xray examination reveals rounded soft tissue shadow with erosion of the dorsal surface and radial border of the distal phalanx. It was treated with marginal excision of the tumour and a part of tendon sheath. Histopathological examination confirms the diagnosis of giant cell tumour of the tendon sheath. CONCLUSION: Giant cell tumour of tendon sheath involving the dorsal aspect of the distal interphalangeal joint of the fingers is rare. Radiologically it produces bone erosion. Involving the dorsal aspect, distal interphalangeal joint and erosion of bone in X-ray are the factors for the high recurrence rate. Surgical marginal excision is the treatment of choice.

KEY WORDS: Cortical erosion, Dorsal aspect, Distal interphalangeal joint, Giant cell tumour, Tendon sheath.

INTRODUCTION: Giant cell tumours are the second commonest tumours in the hand after ganglion cysts. Usually they involve proximal interphalangeal joint and volar aspect. Here we are presenting a case which had distal interphalangeal joint and dorsal aspect, which is a rare entity.

CASE DETAILS: 47 yrs male patient came with the complaint of swelling in the middle finger left hand since two years, the swelling was progressively increased to the present size of $2.5 \mathrm{x} 2 \mathrm{~cm}$. On examination a lobulated swelling which was firm in consistency involving the dorsal aspect of the distal interphalangeal joint of the middle finger was noted, skin over it was free from the swelling and movements at the joint were restricted due to the size of swelling (Fig 1, 2). X-ray examination reveals rounded soft tissue shadow with erosion of the dorsal surface and radial border of the distal phalanx (Fig 3, 4). Diagnosis of giant cell tumour of the tendon sheath or joint capsule made. The procedure planned was for marginal excision under brachial block. Intraoperatively a multilobulated swelling was found involving the dorsal aspect of the insertion of the dorsal hood apparatus and free from the joint and bone (Fig 5). Scalloping and erosion of the underlying bone was also seen which was curetted till bleeding surface. Excised tissue was sent for the histopathological examination and it revealed giant cell tumour of the tendon sheath. Post operative 
period was uneventful. At three months follow up the movements at the distal interphalangeal joint was 5 degrees of fixed flexion deformity to 60 degrees of free flexion.

DISCUSSION: The second commonest tumour of the hand is giant cell tumour after ganglion cysts. Giant cell tumours of the soft tissues are of two types, the commonest being the localised variant and rare one being the diffuse variant. The diffuse type is also called pigmented villonodular synovitis, which most commonly affects knee joint [1]. Giant cell tumour of tendon sheath is seen usually between 30 to 50 years of age, more common in females in the ratio of 3:2. Giant cell tumour of the tendon sheath is associated with arthritis of the distal interphalangeal joint ${ }^{[2]}$ and occasionally with rheumatoid arthritis [3]. Etiology of GCT is unknown. Pathogenic theories are trauma, infection, inflammation, osteoclastic proliferation, disturbed lipid metabolism and neoplasia [4]. Most widely accepted theory is the one proposed by Jaffe et al which states that, the lesion is caused by reactive or regenerative hyperplasia associated with an inflammatory process [5]. Histochemical assays by polymerized chain reaction show that they are polyclonal proliferations ${ }^{[6]}$ and suggesting that they are non-neoplastic proliferations.

Usually two third of the masses presented along volar aspect of the long or middle fingers and involving distal interphalangeal joint [7] and dorsal location is rare. Usual presentation is swelling since years with numbness in the finger. Examination of such swellings reveal non-tender firm lobulated slow growing lesions, firmly adherent to underlying tissues and overlying skin will be free. Differential diagnosis will be tendinous xanthoma, necrobiotic granuloma, foreign body granuloma, epidermoid cyst, knuckle pad, fibroma of tendon sheath, lipoma and ganglion cyst [8].

Plain $x$ ray of the finger show rounded soft tissue shadow with or without cortical erosion due to pressure effects of tumour. The radiological differential diagnosis includes periosteal chondroma, and if any intra-lesional calcification calcific tendinitis and synovial chondromatosis also kept in mind. MRI does not give any clue to the tumour as both T1W and T2W show decreased signal intensities for the tumour. The treatment of choice for the condition is marginal excision of the tumour which involves complete excision of entire tumour with or without part of tendon sheath or joint capsule, sometimes part of the tendon and overlying skin if it is adherent to it. If arthritis of the joint is present it is better to perform an arthrodesis or debridement [2]. A better functional outcome can be achieved with tendon reconstruction and skin grafting of the defect. The histopathology of the tumour shows moderately cellular with sheets of round or polygonal cells with collagenized hypocellular areas and giant cells of variable numbers. Periphery of the lesion is surrounded by xanthoma cells and fibrous capsule. The differentiating features for diffuse type is absence of capsule and few giant cells. Even after meticulous dissection of the tumour the recurrence rate is ${ }^{[9]}$ to $44 \%{ }^{[10]}$. The recurrence rate increases if the distal interphalangeal joint is involved, a dorsal aspect tumour and cortical erosion in $\mathrm{x}$ ray. Some studies recommended radiotherapy to prevent recurrence [11]. With the use of radiotherapy after surgery by Garg[12] and Kotwal[13] reported dramatic reductions in recurrence rates, with total recurrence rates of $0 \%$ and $4 \%$, respectively. Radiotherapy is indicated in patients who had either mitotic figures or possible incomplete excision [13]. In our case we have done complete excision of the tumour and not advised radiotherapy.

CONCLUSION: Giant cell tumour of tendon sheath involving the dorsal aspect of the distal interphalangeal joint of the fingers is rare. Radiologically it produces bone erosion. Involvement of 
the dorsal aspect, distal interphalangeal joint and erosion of bone in X-ray are the factors leading to high recurrence rates. Surgical marginal excision is the treatment of choice.

\section{REFERENCES:}

1. Murphey MD, Rhee JH, Lewis RB, Fanburg-Smith JC, Flemming DJ, Walker EA. Pigmented villonodular synovitis: radiologic-pathologic correlation. Radiographics. Sep-Oct 2008; 28(5):1493-518.

2. Jones FE, Soule EH, Coventry MB. Fibrous xanthoma of synovium (giant-cell tumor of tendon sheath, pigmented nodular synovitis). A study of one hundred and eighteen cases. J Bone Joint Surg Am. Jan 1969; 51 (1):76-86.

3. Reginato A, Martinez V, Schumacher HR. Giant cell tumour associated with rheumatoid arthritis. Ann Rheum Dis. Jul 1974; 33 (4):333-41.

4. Hosaka M, Hatori M, Smith R, Kokubun S. Giant cell formation through fusion of cells derived from a human giant cell tumor of tendon sheath. J Orthop Sci. 2004; 9 (6):581-4.

5. Jaffe HL, Lichtenstein HL, Elsutro CJ. Pigmented villonodular synovitis, bursitis, and tenosynovitis. Arch Pathol. 1941;31:731-65

6. Vogrincic GS, O'Connell JX, Gilks CB. Giant cell tumor of tendon sheath is a polyclonal cellular proliferation. Hum Pathol. Jul 1997; 28 (7):815-9.

7. Garg B, Kotwal PP. Giant cell tumour of the tendon sheath of the hand. J Orthop Surg (Hong Kong). Aug 2011; 19 (2):218-20.

8. Stewart MJ. Benign giant-cell synovioma and its relation to "xanthoma". JBJS. 1948;30B: 5227.

9. Phalen GS, McCormack LJ, Gazale WJ. Giant-cell tumor of tendon sheath (benign synovioma) in the hand. Evaluation of 56 cases. Clin Orthop. 1959; 15: 140-51.

10. Wright CJE. Benign giant-cell synovioma; an investigation of 85 cases. Br J Surg. Jan 1951; 38 (151):257-71.

11. Goda JS, Patil P, Krishnappan C, Elangovan D. Giant cell tumor of the tendon sheath treated by brachytherapy (surface mold) technique-A technical illustration. Brachytherapy. Jan-Mar 2009; 8(1):79-83.

12. Garg B, Kotwal PP. Giant cell tumour of the tendon sheath of the hand. J Orthop Surg (Hong Kong). 2011; 19(2):218-20.

13. Kotwal PP, Gupta V, Malhotra R. Giant-cell tumour of the tendon sheath. J Bone Joint Surg Br. 2000; 82(4):571-3.

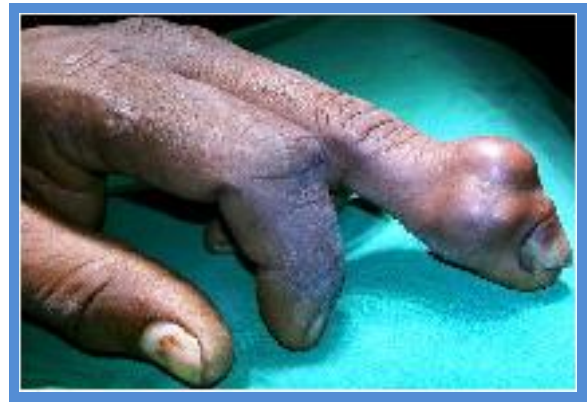

Fig. 1

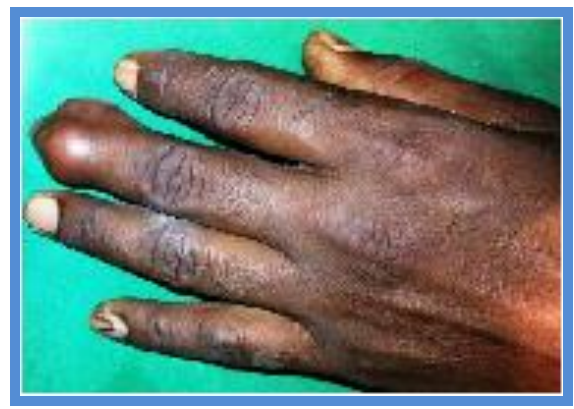

Fig. 2 


\section{CASE REPORT}

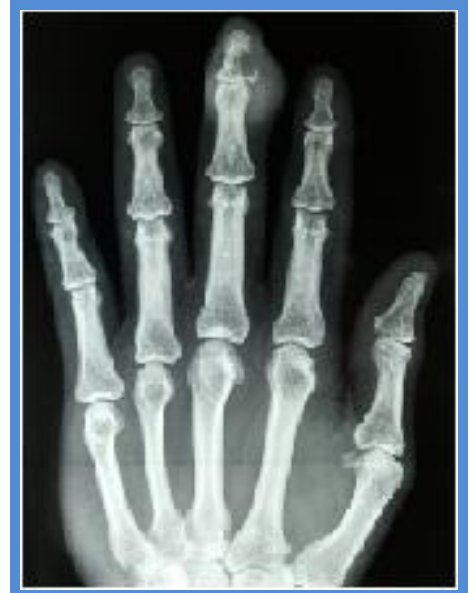

Fig. 3

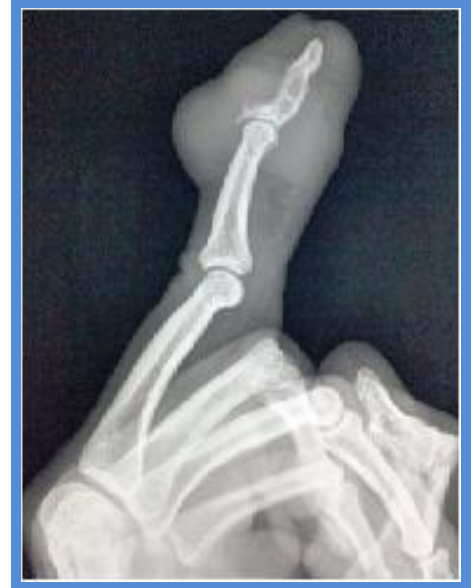

Fig. 4

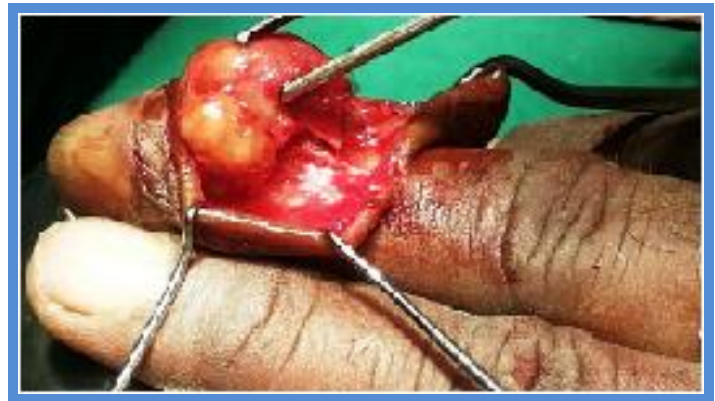

Fig-5

\section{AUTHORS:}

1. Maruthi C.V.

2. Roshan Pais

3. Vedashree M.K.

\section{PARTICULARS OF CONTRIBUTORS:}

1. Assistant Professor, Department of Orthopaedics, M.V.J. Medical College and Research Hospital, Hoskote, Bangalore.

2. Assistant Professor, Department of Orthopaedics, M.V.J. Medical College and Research Hospital, Hoskote, Bangalore.

3. Assistant Professor, Department of Pathology, M.V.J. Medical College and Research Hospital, Hoskote, Bangalore. 